Int. J. Electrochem. Sci., 15 (2020) 12475 - 12490

International Journal of

ELECTROCHEMICAL

SCIENCE

$\underline{\text { WWW.electrochemsci.org }}$

\title{
Investigation of the Electrochemical Performance of Anode- Supported SOFCs under Steady-State Conditions
}

\author{
Yutao Lian, Minggang Zheng ${ }^{*}$
}

School of Mechanical and Electronic Engineering, Shandong Jianzhu University, Jinan, People's Republic of China

"E-mail: why1318@sdjzu.edu.cn

doi: $10.20964 / 2020.12 .74$

Received: 29 August 2020 / Accepted: 22 October 2020 / Published: 31 October 2020

\begin{abstract}
A numerical investigation was conducted on the steady-state electrochemical performance of an anodesupported solid oxide fuel cell (SOFC) with various design parameters and operating conditions. A zerodimensional mathematical model illustrating the electrochemical characteristics of SOFCs was used in this paper. The simulated results showed good agreement with the experimental data. By using this model as a simulation, the steady-state electrochemical performances of SOFCs were studied. Additionally, how the electrode and electrolyte thicknesses, triple-phase boundary (TPB) length, operating temperature, and pressure affected the SOFC performance was investigated. In addition, the effect of the structural and operating parameters on overpotentials was studied. Combining the analyses on the structural and operating parameters, recommendations were provided for optimizing SOFC designs. This work provides systematic suggestions for improving the building of an SOFC electrochemical reaction mechanism model.
\end{abstract}

Keywords: solid oxide fuel cells, electrochemical reaction mechanism, three-phase boundary, polarization, parametric analysis

\section{$\underline{\text { FULL TEXT }}$}

(C) 2020 The Authors. Published by ESG (www.electrochemsci.org). This article is an open access article distributed under the terms and conditions of the Creative Commons Attribution license (http://creativecommons.org/licenses/by/4.0/). 